\title{
Perbaikan Budidaya Polikultur Lidah Buaya (Aloe vera Linn) dan Kacang Panjang (Vigna unguiculata) Menggunakan Biakan Rhizobium
}

\section{Polyculture Cultivation Improvement of Aloe vera Linn and Vigna unguiculata using Inoculation of Rhizobium Strains}

\author{
Sri Purwaningsih ${ }^{*}$, Saefudin ${ }^{2}$, dan Budiarjo ${ }^{2}$ \\ ${ }^{1}$ Balit Mikrobiologi, Puslit. Biologi - LIPI, Jl. Juanda 18 Bogor 16002, *Penulis untuk korespondensi \\ ${ }^{2}$ Balit Botani, Puslit Biologi - LIPI, Jl. Juanda 18 Bogor 16002
}

\begin{abstract}
Polyculture cultivation improvement of Aloe vera Linn (A. vera Linn) and Vigna unguiculata ( $V$. unguiculata) has been done using Rhizobium strains inoculation onto $V$. unguiculata seeds to increase their growth and production. The study was done in Ciomas district, Bogor, using rice paddy field with a total of $24^{\text {th }}$ plots of $1 \times 2,5 \mathrm{~m}^{2}$ width. A. vera Linn was planted until two months old using an interval of $60 \times 60$ $\mathrm{cm}^{2}$. The Rhizobium used were strains number 171, 172, 173, and their combination of those three, which was planted using an interval of $20 \times 35 \mathrm{~cm}^{2}$. The negative controls were uninoculated, without $N\left(K_{1}\right)$ and the positive controls were uninoculated, with urea fertilizer equal to $100 \mathrm{~kg} / \mathrm{ha}\left(\mathrm{K}_{2}\right)$. The experiment design was using Randomized Complete Block Design (RCBD) with four replications. The parameters used were leaves numbers, dry weight of plants, roots, root nodules, and pods production of $V$. unguiculata and leaves number, leaves length and width of $A$. vera. Results showed that isolate number of 172 (isolate of Glycine max Linn.) had given the best results on the production of $V$. unguiculata in the polyculture system with $A$. vera.
\end{abstract}

Key words: Rhizobium strain, polyculture of Aloe. vera Linn and Vigna unguiculata

Diterima: 6 Mei 2003, disetujui: 17 Juni 2003

\section{Pendahuluan}

Tanaman lidah buaya (Aloe vera Linn) termasuk dalam famili Liliaceae, tanaman ini banyak manfaatnya antara lain sebagai bahan baku dalam pembuatan kosmetik, industri farmasi, makanan, minuman, dan lain-lain, sehingga tanaman ini perlu ditingkatkan produksinya.

Kacang panjang (Vigna unguiculata) termasuk dalam famili Leguminoceae yang banyak dibudidayakan masyarakat. Polong, biji dan daunnya banyak dikonsumsi masyarakat sebagai bahan pangan, vitamin dan serat. Lebih dari itu tanaman ini mampu bersimbiosis dengan bakteri penambat nitrogen (N) Rhizobium yang hidup dalam sistem perakarannya. sehingga tanaman dapa memenuhi kebutuhan nitrogen bag pertumbuhannya (Allen and Allen, 1981) Tanaman ini akan meninggalkan bintil akar d dalam tanah sehingga menyuburkan tanah d sekitarnya (Soepardi, 1983).

Interaksi antara dua jenis atau lebi tanaman budidaya dalam suatu pola tanan dapat terjadi secara langsung ataupun tida langsung. Kadang-kadang interaksi in menguntungkan, karena menghasilkan du komoditi dalam satu periode tanam da penghematan waktu, tetapi dapat jug merugikan terutama karena persainga pengambilan hara tanah, senyawa kimi tertentu, cahaya, dan ruang. Interaksi jeni tanaman yang berbeda ini dapat melibatka 
beberapa atau banyak aspek lingkungannya (Odum, 1971; Rice 1974). Dari aspek ekonomi, budidaya tumpangsari lidah buaya dan kacang panjang dapat menguntungkan petani dengan bertambahnya jenis tanaman yang dihasilkan. Tanaman tumpangsari dapat menguntungkan lebih dari $100 \%$ dibanding secara monokultur. Lebih dari itu, kacang panjang yang bersimbiosis dengan Rhizobium akan menguntungkan tanaman di sekitarnya, dengan sumbangan nitrogennya.

Percobaan inokulasi berbagai strain Rhizobium dilakukan sebagai upaya seleksi bakteri penambat nitrogen yang dapat menaikkan kandungan $\mathrm{N}$ tanaman, mengurangi ketergantungan terhadap pupuk kimia, meningkatkan produksi dan pada gilirannya meningkatkan kesuburan tanah. Penambatan nitrogen secara biologis diperkirakan menyumbang lebih dari 170 juta ton nitrogen ke biosfer per tahun, $80 \%$ di antaranya merupakan hasil dari simbiosis antara bakteri Rhizobium dengan tanaman leguminosae (Peoples et. al, 1997 dalam Prayitno et al., 2000). Keberhasilan inokulasi bergantung pada kemampuan biakan Rhizobium yang diinokulasi dalam berkompetisi dengan mikroba yang berada di dalam tanah dan kemampuan adaptasi dengan lingkungannya (Sprent, 1976). Selain itu jumlah sel Rhizobium dan tehnik inokulasi juga sangat besar pengaruhnya terhadap tindakan inokulasi (Freire, 1977). Penggunaan bakteri Rhizobium sebagai pupuk hayati dalam bentuk inokulum sudah banyak dilakukan, namun hasilnya masih bervariasi dan beragam. Inokulasi akan berpengaruh nyata apabila inokulum yang diberikan mampu bersaing dan beradaptasi terhadap lingkungannya, serta cocok dengan tanaman inangnya (Yutono, 1985). Di samping itu jumlah dan efektivitas bakteri asli (indigenous) juga berpengaruh terhadap inokulum yang diberikan (Singleton and Taveres, 1988).

Penelitian ini bertujuan untuk mendapatkan biakan Rhizobium yang cocok, sehingga mampu meningkatkan produksi kacang panjang, selain itu mampu memperbaiki teknik budidaya tumpangsari kacang panjang-lidah buaya, yang selanjutnya diharapkan memperbaiki lingkungan tumbuh tanaman. Interaksi kacang panjang-lidah buaya dan mikroba yang sesuai diharapkan mampu meningkatkan hasil kedua tanaman dan pada gilirannya memperbaiki nilai ekonomi bagi petani.

\section{Metode Penelitian}

Lahan yang digunakan dalam penelitian ini adalah lahan persawahan yang sebelumnya ditanami padi, ubi jalar, dan kacang tanah secara bergantian di desa Ciomas, Bogor. Tanah dibuat petak-petak dengan ukuran $1 \mathrm{x}$ $2,5 \mathrm{~m}^{2}$, sebanyak 24 petak percobaan.

Biakan Rhizobium yang digunakan pada percobaan ini adalah biakan No. 171 dan 173 (isolat bintil akar dari tanaman kacang panjang), No. 172 (isolat bintil akar dari tanaman kedelai), dan biakan campuran (No 171, 172 dan 173). Rhizobium dibiakkan dalam media YEMA miring (Vincent, 1970), dalam tabung reaksi, diinkubasikan selama 7 hari, kemudian masing-masing biakan dipindahkan kedalam erlenmeyer yang berisi $200 \mathrm{ml}$ media YEMA cair dan dikocok dengan kecepatan 120 rpm selama lima hari. Bakteri dalam media YEMA cair mempunyai kepekatan mencapai kurang lebih $10^{9} \mathrm{sel} / \mathrm{ml}$ larutan (bahan I). Sebagai bahan pembawa digunakan campuran gambut : tanah : kapur : arang dengan perbandingan $9: 1: 0,02: 0,01$ (bahan II). Inokulum dibuat dengan perbandingan $3 \mathrm{ml}$ bahan I dan 5 gram bahan II (Rahayu et al., 1990). Benih kacang panjang sebelum ditanam, dicampur terlebih dahulu dengan inokulum Rhizobium dan ditambah air secukupnya agar menempel, kemudian didiamkan selama 2 jam. Penanaman dilakukan secara tugal sebanyak 2 biji per lubang, dengan jarak tanam 20 x 35 $\mathrm{cm}^{2}$. Sebagai kontrol negatif, tanaman tanpa inokulasi dan tanpa dipupuk $\mathrm{N}\left(\mathrm{K}_{1}\right)$, dan kontrol positif berupa tanaman tanpa inokulasi namun dipupuk N, setara dengan $100 \mathrm{~kg} / \mathrm{ha}$ $\left(\mathrm{K}_{2}\right)$. Rancangan yang digunakan adalah Rancangan Acak Lengkap Berblok dengan 4 ulangan.

Bibit tanaman lidah buaya yang diambil dari tunas akar yang telah disemaikan hingga umur dua bulan, selanjutnya ditanam pada petak percobaan kacang panjang secara tumpangsari dengan jarak tanam $60 \times 60 \mathrm{~cm}$. 
Pada umur dua minggu setelah tanam dibuatkan anjir sejajar dengan arah jalur lidah buaya. Penyemprotan hama dan penyakit tidak dilakukan untuk menghindari pencemaran pestisida. Pengairan selama percobaan berlangsung hanya tergantung pada air hujan.

$$
\text { Pengamatan dilakukan terhadap }
$$
produksi polong kacang panjang dan dilakukan pemanenan pada saat terbentuk polong muda. Tanaman dipanen pada umur 90 hari (pada saat polong sudah tidak terbentuk). Parameter yang diamati adalah jumlah daun, bobot kering tajuk, akar dan bintil akar.

\section{Hasil dan Pembahasan}

Hasil analisa tanah menunjukkan bahwa pH tanah antara 6,1-6,4 (sedang), teksturnya terdiri dari pasir $67,94 \%$, debu $19,65 \%$ dan liat $12,41 \%$. Komposisi tanahnya mengandung $\mathrm{C}$ organik $0,69 \%$ (sangat rendah), $\mathrm{N}$ total $0,16 \%$ (rendah), $\mathrm{P}_{2} \mathrm{O}_{5}$ tersedia $11,50 \mathrm{ppm}$ (sedang), $\mathrm{Ca}$

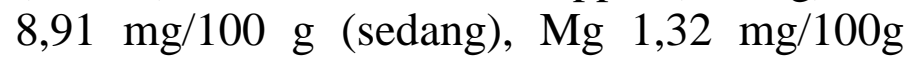
(sedang), K 0,59 mg/100 g (tinggi), Na 0,19 $\mathrm{mg} / 100 \mathrm{~g}$ (sedang). Total basa dapat ditukar $11,01 \mathrm{mg} / 100 \mathrm{~g}$ (sangat rendah) dan Al tak terukur. Dari hasil pengukuran dapat dikatakan bahwa $\mathrm{pH}$ tanah termasuk sedang dan persentase $\mathrm{N}$ total rendah. Seperti yang dikatakan oleh Soepardi (1983) bahwa jumlah $\mathrm{N}$ total yang diharapkan dalam lapisan tanah untuk pertumbuhan tanaman adalah $0,02-0,5 \%$.

Hasil percobaan menunjukkan bahwa tanaman yang diinokulasi dengan biakan Rhizobium mampu membentuk bintil akar. Biakanan Rhizobium yang diinokulasikan tersebut berasal dari biakan yang telah terseleksi dan terbukti efektif sebelumnya dengan tanaman inangnya itu sendiri. Hasil pengamatan menunjukkan bahwa tanaman yang tidak diinokulasi mampu membentuk bintil akar. Hal ini menunjukkan bahwa tanah pada lahan percobaan mengandung bakter Rhizobium asli, karena pada perlakuan tanama tanpa diinokulasi dan tanpa dipupuk $\mathrm{N}\left(\mathrm{K}_{1}\right.$ mampu membentuk bintil akar. Pasaribu et a (1989) mengatakan bahwa berhasilnya suat tindakan inokulasi apabila biakanan Rhizobiun yang diinokulasikan merupakan suat inokulum yang lebih unggul dari pada bakter alami.

Inokulasi biakan Rhizobium pada tanama kacang panjang memberikan hasil yan bervariasi terhadap pertumbuhan dan produks polong basah, ada yang memberikan hasil yan lebih besar dibandingkan dengan tanaman tanp diinokulasi dan tanpa dipupuk $\mathrm{N}\left(\mathrm{K}_{1}\right)$, da sebaliknya. Hasil yang lebih tinggi denga tanaman tanpa diinokulasi dan tanpa dipupuk 1 $\left(\mathrm{K}_{1}\right)$ dan bahkan lebih tinggi dengan tanama yang tanpa diinokulasi dan dipupuk $\mathrm{N}\left(\mathrm{K}_{2}\right.$ menunjukkan bahwa biakan-biakan tersebu mempunyai kemampuan simbiosis yang efektif mampu menambat nitrogen dari udara mengakibatkan pertumbuhan dan produks kacang panjang meningkat. Pasaribu (1983 mengemukakan bahwa simbiosis yang efektif da efisien akan menghasilkan $\mathrm{N}$ tertambat yan tinggi, sehingga pertumbuhannya akan menjad lebih baik. Hasil yang lebih rendah denga tanaman tanpa diinokulasi dan tanpa pupuk $\mathrm{I}$ $\left(\mathrm{K}_{1}\right)$, mungkin disebabkan bakteri tersebut tida mampu bersaing dan beradaptasi dengan bakte tanah (indigenous), dugaan ini didukung denga ditemukannya bakteri Rhizobium yang mamp membentuk bintil akar pada tanaman tanp diinokulasi dan tanpa dipupuk $\mathrm{N} \quad\left(\mathrm{K}_{1}\right)$ Kemampuan tanaman membentuk bintil aka sangat tergantung pada beberapa faktor, antaranya adalah kecocokan atau keserasia antara tanaman bersangkutan dengan Rhizobiur inokulan dan kemampuan bersaing denga bakteri yang ada di dalam tanah, ketersediaa unsur hara dan $\mathrm{pH}$ tanah (Frederick, 1975 an Fred et al, 1976). 
Budidaya Polikultur Lidah Buaya dan Kacang Panjang

Tabel 1: Nilai rata-rata jumlah daun (JD), bobot kering tajuk (BKT), akar (BKA), bintil akar (BKB) dan produksi polong basah (PP) kacang panjang setelah perlakuan inokulasi Rhizobium (saat panen berumur 90 hari)

\begin{tabular}{lccccc}
\hline \multicolumn{1}{c}{ Perlakuan } & JD & BKT (gram) & BKA (gram) & BKB (gram) & PP (gram) \\
\hline \hline 171 & 10,23 & $148,03 \mathrm{bcd}$ & $14,79 \mathrm{ab}$ & 0,14 & $2072 \mathrm{ab}$ \\
172 & 14,50 & $178,63 \mathrm{~d}$ & $13,91 \mathrm{ab}$ & 0,26 & $2595 \mathrm{~b}$ \\
173 & 15,25 & $99,57 \mathrm{a}$ & $18,31 \mathrm{~b}$ & 0,21 & $2035 \mathrm{ab}$ \\
$171+172+173$ & 11,81 & $160,38 \mathrm{~cd}$ & $11,77 \mathrm{a}$ & 0,18 & $1650 \mathrm{a}$ \\
Kontrol $(-\mathrm{N})$ & 12,90 & $118,26 \mathrm{ab}$ & $9,67 \mathrm{a}$ & 0,16 & $2025 \mathrm{ab}$ \\
Kontrol $(+\mathrm{N})$ & 13,87 & $128,55 \mathrm{abc}$ & $13,90 \mathrm{ab}$ & 0,35 & $2047 \mathrm{ab}$ \\
BNT 5\% & NS & 38,49 & 5,16 & $\mathrm{NS}$ & 626,32 \\
\hline
\end{tabular}

Keterangan: angka yang diikuti dengan huruf yang sama pada tiap kolom tidak berbeda nyata pada taraf 0,05 uji BNT

Tabel 1. menunjukkan bahwa pada parameter jumlah daun dan bobot kering akar nilai tertinggi diperoleh pada tanaman yang diinokulasi dengan biakan No.173, masingmasing mengalami peningkatan sebesar $18,21 \%$ dan $89,34 \%$ dibandingkan dengan tanaman tanpa diinokulasi dan tanpa dipupuk
$\mathrm{N}\left(\mathrm{K}_{1}\right)$. Sedangkan untuk bobot kering tanaman tajuk, bintil akar dan produksi polong basah nilai tertinggi dicapai pada tanaman yang diinokulasi dengan biakan No.172, masingmasing mengalami peningkatan sebesar $51,04 \%, 62,5 \%$ dan $28,14 \%$.

Tabel 2. Pertumbuhan lidah buaya dari umur 2 bulan hingga umur 6 bulan dalam sistem polikultur dan monokultur.

\begin{tabular}{ccccccc}
\hline & \multicolumn{5}{c}{ Rata-rata (cm) } \\
\cline { 2 - 7 } Umur (bln) & \multicolumn{3}{c}{ Tumpangsari } & \multicolumn{3}{c}{ Monokultur } \\
\cline { 2 - 7 } & $\begin{array}{c}\text { Jumlah. } \\
\text { Daun }\end{array}$ & $\begin{array}{c}\text { Panjang.daun } \\
(\mathbf{c m})\end{array}$ & $\begin{array}{c}\text { Lebar daun } \\
(\mathbf{c m})\end{array}$ & $\begin{array}{c}\text { Jumlah } \\
\text { daun }\end{array}$ & $\begin{array}{c}\text { Panjang.daun } \\
(\mathbf{c m})\end{array}$ & $\begin{array}{c}\text { Lebar daun } \\
(\mathbf{c m})\end{array}$ \\
\hline \hline 2 & 3,2 & 7,4 & 1,4 & 3,2 & 7,4 & 1,4 \\
3 & 4,0 & 8,8 & 1,9 & 4,1 & 8,7 & 1,8 \\
4 & 6,7 & 14,7 & 3,2 & 6,6 & 13,8 & 3,5 \\
5 & 7,2 & 24,7 & 4,1 & 7.3 & 28,6 & 4,3 \\
6 & 7,9 & 28,4 & 5,2 & 8,2 & 30,3 & 5,5 \\
\hline
\end{tabular}

Hasil analisa tanah menunjukkan bahwa kandungan nitrogen relatif kecil yaitu $0,16 \%$. Inokulasi Rhizobium dalam kondisi demikian cukup baik dan mampu meningkatkan pertumbuhan dan produksi kacang panjang. Namun demikian kenaikan ini belum mampu meningkatkan pertumbuhan lidah buaya. Hal ini diduga berhubungan dengan persaingan hara dan cahaya matahari bagi pertumbuhan lidah buaya.

Hasil pengukuran terhadap pertumbuhan lidah buaya hingga akhir panen kacang panjang diketahui bahwa, dari bibit dengan jumlah daun rata-rata 3,2 helai, panjang daun $7,4 \mathrm{~cm}$ dan lebar daun 1,4 cm di awal penanaman (umur 2 bulan) setelah tanaman berumur 4 bulan menjadi rata-rata 6,7 helai, lebar rata-rata 3,2 $\mathrm{cm}$ dan panjang helaian daun rata-rata $14,7 \mathrm{~cm}$. Hingga panen pertama dapat diketahui bahwa tanaman lidah buaya hampir tidak terpengaruh oleh tanaman kacang panjang sampai batas panen pertama (umur tiga bulan). Hal ini dapat ditunjukkan bahwa rata-rata pertumbuhan tanaman lidah buaya yang dibudidaya secara monokultur (sampai umur 3 bulan) hampir sama, pada saat itu intersepsi dan absorpsi dari sumber daya pertumbuhan berlangsung tanpa adanya persaingan. Namun demikian pertumbuhan rata-rata setelah 6 bulan, tanaman yang dibudidaya secara monokultur pertumbuhannya mulai nampak lebih cepat dibandingkan dengan tanaman tumpangsari (Tabel 2). Hal ini disebabkan karena tanaman saling bersaing dalam absorpsi sumber daya 
pertumbuhan, selain itu berkaitan dengan kompetisi hara juga berhubungan dengan intensitas cahaya yang berkurang dibandingkan budidaya secara monokultur. Untuk mengetahui lebih jauh pengaruh persaingan hara, ruang dan cahaya, maka kajian lebih jauh secara fisiologis akan nampak setelah lidah buaya dipanen.

Dalam sistem tumpangsari tanaman lidah buaya dan jahe gajah di Subang (Jabar) dilaporkan bahwa pada satu ha lahan dapat ditanam hingga 40 ribu tanaman, sehingga amat menguntungkan petani (Sintawardani, 1998). Bibit lidah buaya yang diterima di pasaran umum adalah umur 11-13 bulan dengan ukuran tebal lebih dari $1 \mathrm{~cm}$, lebar lebih kurang 10-12 cm dan panjang antara 50-70 cm dengan bobot lebih dari 4,5 g. Ukuran bobot dan besar pelepah lidah buaya yang tidak memenuhi standar kurang dihargai oleh pasar. Dengan sistem tumpangsari antara kacang panjang dan lidah buaya akan berpengaruh setelah tanaman lidah buaya berumur 6 bulan. Dengan sistem tumpangsari tanaman kacang panjang dan lidah buaya secara berkesinambungan petani diuntungkan dari segi tambahan produk samping, tetapi juga ringan dari segi pengolahan lahan karena mampu menahan gulma, namun pengaturan sistem tumpangsari disusun agar persaingan terjadi sekecil mungkin (Rachman, 2002). Berbagai penelitian menunjukkan bahwa peningkatan populasi salah satu jenis tanaman akan menurunkan hasil jenis tanaman yang lain dalam sistem tumpang sari (Fawuzi et al., 1982; Osiru and Kibira, 1981), jadi populasi tanaman merupakan faktor utama dalam menyusun sistem tumpangsari, karena petani mengharapkan hasil tanaman tidak terganggu, namun masih mendapatkan tambahan hasil.

\section{Kesimpulan dan Saran}

Pengaruh inokulasi biakan Rhizobium terhadap pertumbuhan dan hasil polong kacang panjang yang ditumpangsarikan dengan tanaman lidah buaya ditentukan oleh beberapa faktor yang mencakup aspek-aspek lingkungan dan ciri biologi biakanan Rhizobium, tanaman kacang panjang, dan lidah buaya, sehingg aspek-aspek ini perlu dipelajari lebih lanjut.

Biakan No.172 (isolat dari bintil aka tanaman kedelai) memberi hasil yang terbai untuk produksi kacang panjang dalam sisten budidaya secara tumpangsari dengan lidal buaya. Biakan tersebut dapat dikembangka sebagai inokulan pupuk hayati untuk tanama kacang panjang.

\section{Daftar Pustaka}

Allen, O.N and E.K. Allen. 1981. The leguminosae The University of Winconsin Press Madison. 812 p.

Fawuzi. M.O.A., S.B.C. Wanki and D. Nangju 1982. Plant density effects on growth, yield leaf area index and light transmission o intercropped Maize and Vigna unguiculat (L) Walp. In Nigeria. J.Agric. Sci. 99: 19-23

Fred. E.B., I.L. Balwin and Elizabeth Mc. Cox 1976. Root Nodule Bacteria and Leguminou plants. Univ. Press. 343 p.

Frederick. L.R. 1975. Soybean inoculation. Ir R.M. Goodman (ed) Expanding the use o Soybean. Intern. Agr. Publ. College o Agriculture Univesity of Illinois at Urban Campaign.

Freire. J.R.J. 1977. Inoculation of Soybean. In. J.N Vincent, A.s. whitney and J. Bose (eds) Exploiting the legume Rhizobium symbiosi in tropical agriculture. Coll. Trop. Agric Misc. Publ. 145. Depart. Agron. Soil. Sc Univ. Hawaii. p: 335-379.

Odum EP. 1971. Fundamental of Ecology. 3 th ed. W E. Saunder Co. Philadelphia, London.731 p.

Osiru. D.S.O and G.R. Kibira, 1981 Sorghum/pigeonpea and millet/groundnu intercropping mixtures with special referenc to plant populations and crop arrangemen Proc. Intern. Workshop on Intercroppin Hyderabat. India. p: 78-85.

Pasaribu. D. 1983. Hara Nitrogen Kedelai. dalar Josodiwondo dkk. Mikrobiologi Indonesia. Kumpulan Makalah Konggre Nasional Mikrobiologi ke III. Jakarta 23-2 Nopember 1981. h: 385-388. 
Budidaya Polikultur Lidah Buaya dan Kacang Panjang

Pasaribu. D. Sunarlim, Sumarno et al. 1989. Penelitian Inokulasi Rhizobium di Indonesia. dalam M. Syam, Rusdi \& A. Widjono. Risalah Lokakarya Penelitian dan Penambatan Nitrogen Secara Hayati padaKacangkacangan. Bogor 30-31 Agustus 1988. Pusat Penelitian Tanaman Pangan. Departemen Pertanian. Pusat Penelitian dan Pengembangan Biotehnologi, Bogor. h: 5-29.

Prayitno, J., J.J. Weinman, M.A. Djordjevic et al. 2000. Pemanfaatan Protein Pendar Hijau (Green Fluorescent Protein) Untuk Mempelajari Kolonisasi Bakteri Rhizobium. Prosiding Seminar Nasional Biologi XVI. h: 372-377.

Rachman. A. 2002. Sifat agronomi dan daya saing tanaman tembakau dalam sistem tumpangsari tembakau-sorghum pada berbagai kerapatan tanam. Jurnal Ilmu Pertanian. Fakultas Pertanian, UGM. h: 11-19.

Rahayu, S.H., Latupapua, H.J.D dan S. Abdulkadir. 1990. Uji viabilitas biakan Rhizobium dalam beberapa bahan pembawa. Laporan Tehnik Sumber daya Hayati 1989/1990. Puslitbang Bologi-LIPI. h: 31-35.

Rice RL. 1974. Allelopathy. Academic Press. London. $444 \mathrm{p}$.
Singleton. P.W and J.W. Taveres. 1988. Inoculation Response of Legume in Relation to the number and effectiveness of indigenous Rhizobium population. Appl and Enveronment Microbiol. p: 1013-1018

Sintawardani. 1998. Laporan Teknik. Puslitbang Kependudukan dan Pendayagunaan Potensi Wilayah-LIPI, Jakarta.

Soepardi G. 1983. Sifat dan Ciri Tanah. Terjemahan The Nature and Properties of Soils (Buckman, H, O. and N. C. Brady, 960). the Mc. Millian Co, New York, IPB, Bogor. h. 85.

Sprent JI. 1976. Symbiotic Nitrogen Fixation in Plants. P.S. Nutman (ed) Combridge Univ. Press. $584 \mathrm{p}$

Vincent. J.M. 1970. A Manual for the Practical Study of the Root Nodule Bacteria. International Biological Programme. London. Handbook No 15. 164 p.

Yutono. 1985. Inokulasi Rhizobium pada kedele. Dalam. S. Somaatmadja, M. Ismunadji, Soemarno, M. Syam, S.O. Manurung dan Yuswadi (eds). Kedele, Badan Litbang Pertanian, Bogor. h:.27-230. 